\title{
Customer Experience Marketing (CEM), Customer Satisfaction and Customer Trust Affects Customer Loyalty: A Study on Star Hotels in Jakarta Province
}

\author{
Dewi Trini \\ Sekolah Pascasarjana, Universitas Pancasila, Indonesia \\ RS Ibu dan Anak Grand Family \\ E-mail:dewi.trini65@gmail.com \\ M. Noor Salim \\ University of Mercu Buana, Indonesia \\ E-mail: m_noorsalim@yahoo.com
}

Received: Sep. 6, 2018

Accepted: Sep. 18, 2018

Published: December 24, 2018

doi:10.5296/bms.v9i2.13615

URL: https://doi.org/10.5296/bms.v9i2.13615

\begin{abstract}
This study aims to examine customer experience marketing (CEM), customer satisfaction, consumer trust affects customer loyalty for star hotels in Jakarta, Indonesia. This study employs a causal and descriptive research using a survey research method. This study hypothesizes that (1) CEM has a significant effect on customer loyalty, (2) CEM has a significant effect on customer satisfaction, (3) customer satisfaction has a significant effect on customer loyalty, (4) customer satisfaction has a significant effect on customer trust and (5) customer trust has a significant effect on customer loyalty. The sample used is 200 respondents that were obtained from the star hotels' guests in Jakarta. A structural equation modelling (SEM) is employed and the results reveal that only CEM has a significant impact on customer loyalty meanwhile customer satisfaction and customer trust have no impact on customer loyalty.
\end{abstract}

Keywords: customer experience marketing (CEM), customer satisfaction, customer trust, customer loyalty, Jakarta 


\section{Introduction}

Indonesia's tourism growth exceeds the average of the world's growth is $10.63 \%$ in 2015 and the growth boosts the Ministry of Tourism confidence to increase the target of foreign tourists visiting in 2016 from 10 million to 12 million. The number of foreign tourist arrivals according to the highest entrance is through the Ngurah Rai, Soekarno Hatta and Batam. The second entrance door is DKI Jakarta which is the capital of Indonesia and the largest city in Indonesia. Accommodation business in Indonesia from year to year is increasing, as well as for DKI Jakarta.

The number of star hotels increased from 205 to 228 or $11.2 \%$ in 2015 . The number of guests per day in star hotels in Jakarta decreased by $7.3 \%$ in 2015, this must be a concern especially for hotel entrepreneurs to make breakthroughs in efforts to increase growth of hotel guests. The room occupancy rate of star hotels in DKI Jakarta during 2015 decreased from January to May 2015. Cumulatively the room occupancy rate is the same as the previous year of $58 \%$.

Griffin (2005) reveals that having loyal customers means that the company gets various benefits. Loyalty is not only measured by the number of guests' visits (visits' frequency), but also the extent to which the guest is loyal in using the attributes or supporting facilities provided by the hotel. Prior to research,a preliminary research is conducted to examine the hotel business environment using a short statement survey from 30 Lumire hotel guests in Central Jakarta Senen, Ibis Mangga Dua and Amos Cozy. The questions is mostly based on the aspects of services that need to be improved.

Respondents' responses to hotel services are still found to be the most dissatisfied and very dissatisfied with aspects of customer value, hotel facilities, and hotel location. Generally, there are still many who give a satisfactory assessment, meaning that there is still much to be improved. Further, it can be concluded that (1) the star hotel occupancy rate in DKI Jakarta during 2015 decreased in January to May 2015, (2) low customer loyalty is indicated by customer satisfaction that has not been received for hotel facilities, completeness of services, conditions and hotel room facilities, (3) there is still a gap between what the hotel promises about services provided that are not in accordance with what is received by consumers has made the level of consumer confidence that is still low, 4) ease of access to hotel locations is not as expected, congestion constraints, (5) the hotel's efforts to make services able to make consumers have a deep impression have an impact on the rational, emotional, and spiritual aspects that have not been proven, and (6) customers feel that the costs incurred with the services received are not appropriate.

\section{Literature Review}

Based on the results of a descriptive study by Campos and Marodin (2012), customers show that $86 \%$ of customers dare to pay more just to get a memorable experience. Building a customer experience is one strategy to win the market. Yang and He (2011) revealed in the research literature that the experience given by companies to consumers can increase consumer loyalty by $5 \%$. Through customer experimental marketing can also create 
memorable experiences in the minds of consumers Haghshenas et al. (2013) customer experience arises in consumers after consumers use the product or service to make a decision.

According to Schmitt (2014), CEM is a strategy for companies to manage customer experience through products created or experiences provided through services provided. Fouladivanda, et al. (2013) emphasized that creating value for customers is not just selling an experience, but also how that experience can give a deep impression. Jhamb and Kiran (2012) stated that a company that manages its customer experience well will have an impact on achieving corporate profits and creating customer loyalty. Schmitt (2014) calls it the "Age of Experience" where when consumers have a special impression of a product and service, it will lead to greater emotional improvement than before, and encourage buyers to consume.

The dimensions used in this study refer to Pozza (2014), namely sense, feel, act, think, and relate. First, a sense in the context of Experiential Marketing is the five senses as a tool to feel the products and services offered. Smilansky (2009) revealed that the purpose of sense marketing is to give the impression of beauty, pleasure, beauty, and satisfaction through sensory stimulation. Second, feel is a stimulus that can lead to positive thoughts and opinions. Taste experience refers to "the customer's emotions, moods, and deep feelings that are passed down from consumption of products and services" (Maghnati et al, 2012; Yuan and Wu, 2008). The purpose of feeling experiences is to drive emotional stimuli to influence consumers' moods. Third, think in the Experience Marketing theory said that a good feeling will bring customers to think positively so as to provide good opinions on the company's products and services. Schmitt (2007) revealed that think can be used to conduct marketing campaigns with three types: (1) a sense of surprise: this surprise is needed to attract attention and invite customers to want to think creatively. (2) A Dose of Intrigue is something that is a continuation of a surprise. (3) A Smack Provocation. Provocation can cause consumer attention. Fourth, an act is the act of the consumer in making a purchase that is influenced both by the outside and the opinion from within. Fifth, relate is a relationship or lifestyle perceived by a customer. Relate marketing, is a combination of sense, feel and marketing thinking that aims to associate individuals with something that is outside of themselves. 'Relate' relates to the culture of a person and group that can create a social identity. A marketer must be able to create a social identity (generation, nationality, and ethnicity) for his customers with the products or services offered. Marketers can use cultural symbols in advertising campaigns and Web designs that are able to identify specific customer groups.

Kotler and Keller (2012) suggested that consumers are always looking for products or services that can provide maximum value to consumers. With all the limitations of information on price, knowledge, mobility, and income. Providing good and consistent service quality is difficult but beneficial for businesses engaged in services (Zeithaml, Berry, and Parasuraman, 1988). Consumer satisfaction theories have evolved as quoted by Pozza (2014), Kotler and Keller (2012) and Holjevac, Marcovic and Raspor (2012).

The object of this research is a star hotel so researchers will also use dimensions that generally become the expectations of hotel consumers (Holjevac, et al. 2012; Crandall and 
Eshelman (2002); and Vinagre and Neves (2008), namely: (1) Products, namely rooms where to stay, restaurants, facilities needed such as swimming pools and entertainment rooms, (2) Support employees in services, (3) The arrival of guests at the hotel, such as reservation matters, delivering luggage to the room and welcome drinking, (4) Location of the location of the hotel, such as the condition of the hotel and health insurance from and to the hotel, (5) Environmental security, (6) Comfort atmosphere.

Consumer trust involves two or more parties who have interactions or interests. In the context of the relationship between producers and consumers, Sirdesmukh, Singh, and Sabol (2002) suggest that trust is the belief of one party regarding the intent and behavior of the other. Moellering (2006) cited trust as a psychological state consisting of a desire to accept an unpleasant situation based on a positive expectation of the desire or behavior of another party. A similar view by Moellering (2006) that trust is a desire from a party to accept unpleasant actions from other parties based on a hope that the other party will take certain actions that are very important for the giver of trust. Meanwhile, Colquitt et al. (2009) define trust as a desire to rely on an authority based on positive expectations of action.

Kotler and Keller (2012) suggested that trust is a cognitive component of psychological factors. Trust is related to the belief that something is right or wrong on the basis of evidence, suggestion, authority, experience, or intuition. Sirdesmukh, Singh, and Sabol (2002), states that trust is a psychological condition in the form of an intention to accept the uncertainty of positive expectations for the intentions and behavior of others.

Salo and Karjaluoto (2007), defining trust in the six basic elements are as follows (1) Trusting beliefs, (2) Trusting intention, (3) Trusting behavior, (4) System trust, (5) dispositional trust, (6) Situational decision to trust decisions. Based on exposure to consumer confidence, as well as the object of this research namely star hotel services, it will be relevant if consumer trust theory is useful in reviewing hotel services. Robbins and Judge (2007) stated that there are four key dimensions in the concept of trust, namely (1) Integrity, refers to honesty and truth, (2) Competence, related to the knowledge and technical and interpersonal skills of individuals, (3) Consistency, related to reliability, predictive ability and accurate individual assessment in handling situations, (4) Openness refers to three aspects of interpersonal communication, namely: willingness to self-disclosure provided that the disclosure is adequate; willingness to act honestly with other people's messages; and have feelings and thoughts. Based on the description above, it can be concluded that the dimension of trust in this study is a star hotel, determined to include integrity, competence, consistency, and openness.

Omanukwue (2013) asserts that consumer loyalty will be achieved if consumers want to buy back or reuse the same goods/services because of the quality of the product or service itself. Griffin (2005) argues that a customer is said to be loyal or loyal when the customer shows buying behavior on a regular basis or there is a condition where customers buy at least twice in a certain time interval. Griffin's opinion (2005) provides a broader dimension. First, customer loyalty can be measured by the frequency of customer stays in a certain period. 
Secondly, a measure of customer loyalty develops on purchasing behavior towards new services issued by the company. Third, customer loyalty is the attitude of the customer in providing recommendations for others to stay at the hotel.

Kheng, et al (2010) define consumer loyalty is a level where consumers have the behavior to repurchase from service providers, have a good impression of the services provided by service providers. Halimi, Chavosh, and Choshali (2011) stated that a manager and marketer must always pay attention to consumer loyalty as the most important factor to develop if they want to maintain the sustainability of the company and increase the profitability of the company.

Makodongan (2010) in his research on the analysis of the application of customer relationship management programs on his relationship with guest loyalty at Swiss Belhotel Maleosan, Manado city, stated that the number of loyal customers may not be as much as only $20 \%$ of the total customers in a company. The contribution that can be given to company profits can reach $80 \%$, while the rest can be donated to loyal customers.

Aspfors (2010) asserts that the most important aspect of a business is winning consumer loyalty. Consumers will be very happy if the services provided by entrepreneurs have diverse service attributes, this will also have an impact on the emergence of buying interest and the perception of good service quality in the eyes of consumers (Markovic, S, Raspor and S, Segaric, 2010. The second strategy to be able to create hotel guest customer loyalty in Indonesia is by building quality relationships with consumers Campos and Marodin (2012) explained that hotel industry entrepreneurs must be able to work together through building relationships with consumers.

Merisavo (2008) uses the following dimensions to measure consumer loyalty (1) Behavioral loyalty, including aspects of the purchase, use of products/services, visits to hotels, and recommending to others, (2) Attitudinal loyalty, including attitude towards the brand (brand attitude), brand image, consumer knowledge of the brand (brand knowledge), satisfaction, and perception of the service provided (service perceptions), (3) the ultimate goal of the success of a company in establishing a relationship with its customers is to form strong loyalty.

Omanukwue (2013) in his research used two dimensions of consumer loyalty, namely: based on the aspect of attitude (attitude) and behavior (behavior). Based on the description above and adapted to this study, the researcher sets a dimensional conclusion to measure the variables of hotel consumer loyalty based on Sorce (2002), Omanukwue (2013) and Bobalca (2013), namely: cognitive, affective, conative, action and behavioral loyalty. 


\section{Theoritical Framework}

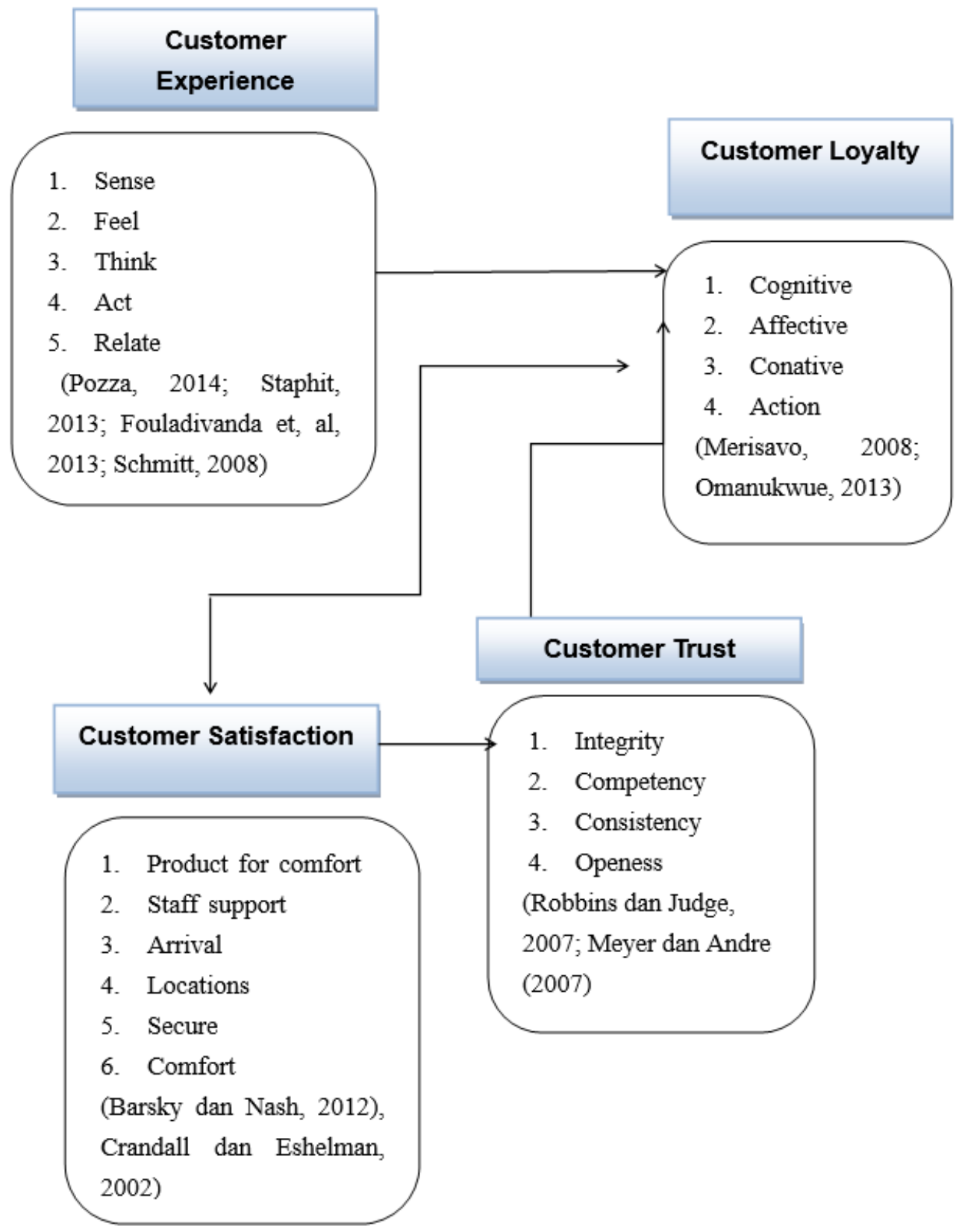

\section{Method}

This research is a combination of causal and descriptive research. The descriptive research aims to obtain an overview of the characteristics of a variable based on the data that has been analyzed, while causality research is a type of research that aims to determine the relationships and influences between variables through a hypothesis testing. (Sekaran, 2003; Cooper and Schindler, 2006).

This study was conducted on several star hotels operating in the Jakarta area through an assessment of the perception of the guests who had stayed at the hotels studied. The selection of sample members from each of the 4-star hotels in this study was carried out by means of 


\section{Macrothink Institute ${ }^{\mathrm{TM}}$}

judgment sampling, namely the respondents who were considered capable of answering the problem of this research with the number of samples of each hotel were as many as 50 respondents.

The descriptive statistical analysis aims to provide data descriptions of available research variables so that it is more informative to describe. The statistics used in this study, namely the proportion. Verification analysis aims to test hypotheses between research variables. Hypothesis testing will lead to the conclusion to accept the hypothesis or reject the hypothesis. The error or alpha value in this study was set at 5 percent. To test the research model that has been proposed, SEM (Structural Equation Modeling) analysis will be used. Statistical data processing using Structural Equation Model (SEM), stated Fonnel (Ghozali, 2006) that the main benefits of SEM compared to the first generation of multivariate such as principal component analysis, factor analysis, discriminant analysis, or multiple regression, SEM has higher flexibility for researchers to connect between theory and data.

Stages of the statistical hypothesis test used to refer to Hair et al. (2010), and Cooper and Schindler (2006), Stages of SEM Analysis based on Hair et al (2010) are as follows (1) Stage 1: Model Specifications, (2) Stage 2: Model identification, (3) Stage 3: Model Estimates, (4) Stage 4: Model Evaluation.

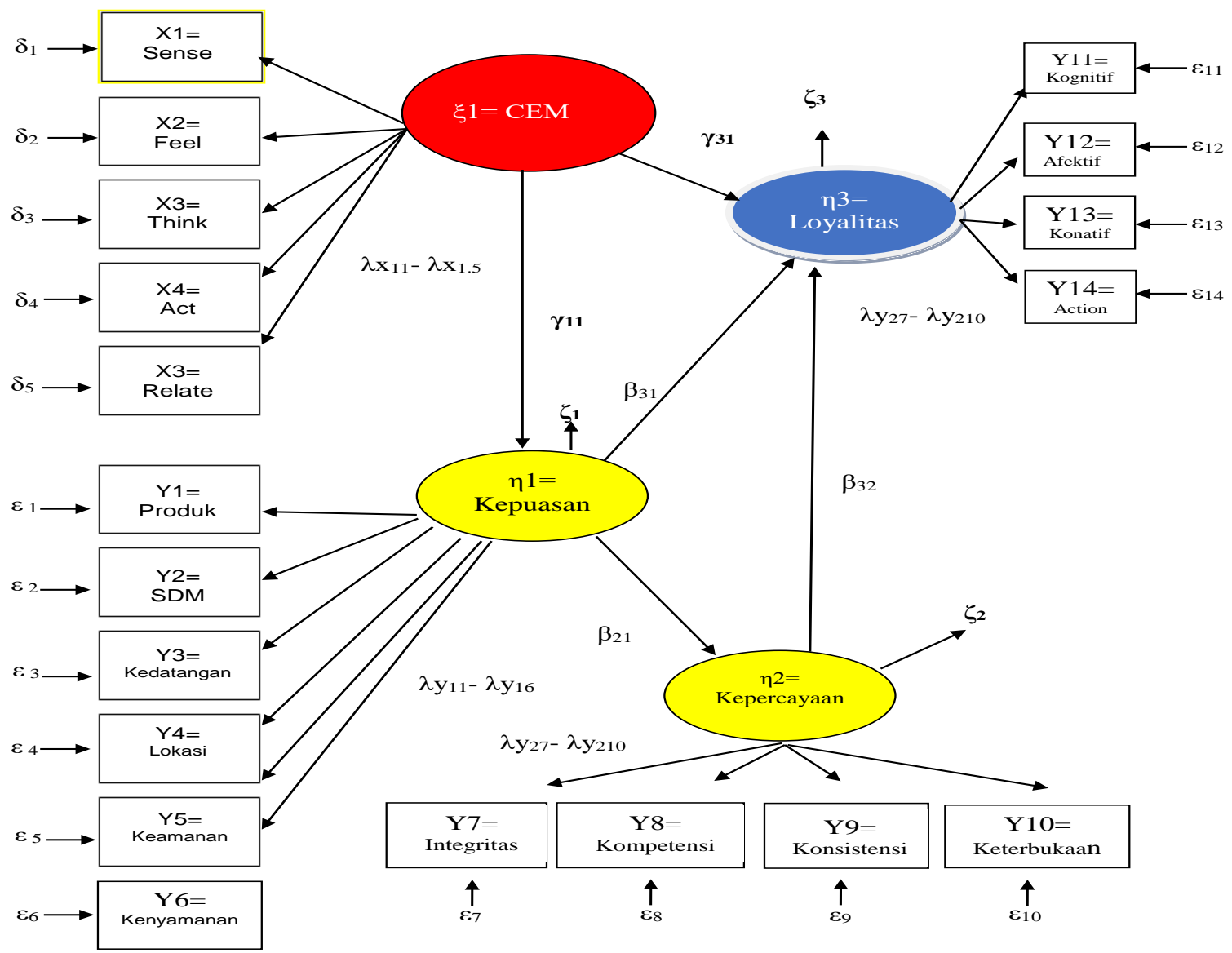


Note:

$\xi_{1}($ Ksai 1$)=$ Exogenous latent variable of CEM

$$
\begin{aligned}
& \mathrm{X}_{1}=\text { sense variable } \\
& \mathrm{X}_{2}=\text { feel variable } \\
& \mathrm{X}_{3}=\text { think variable } \\
& \mathrm{X}_{4}=\text { act variable } \\
& \mathrm{X}_{5}=\text { relate variable }
\end{aligned}
$$

$\eta_{1(\text { Eta }}$ 1) $=$ Endogenous latent variable of satisfaction

$$
\begin{aligned}
& \mathrm{Y}_{1}=\text { product variable } \\
& \mathrm{Y}_{2}=\text { human resource variable } \\
& \mathrm{Y}_{3}=\text { arrival variable } \\
& \mathrm{Y}_{4}=\text { location variable } \\
& \mathrm{Y}_{5}=\text { safety variable } \\
& \mathrm{Y}_{6}=\text { comfort variable }
\end{aligned}
$$

$\eta_{2}\left(\begin{array}{ll}\text { Eta } & 2)\end{array}=\right.$ Endogenous latent variable of trust

$$
\begin{aligned}
& \mathrm{Y}_{7}=\text { integrity variable } \\
& \mathrm{Y}_{8}=\text { competence variable } \\
& \mathrm{Y}_{9}=\text { consistency variable } \\
& \mathrm{Y}_{10}=\text { openness variable }
\end{aligned}
$$

$\eta_{3 \text { (Eta 3) }}=$ Endogenous latent variable of loyalty

$$
\begin{aligned}
& \mathrm{Y}_{11}=\text { cognitive variable } \\
& \mathrm{Y}_{12}=\text { affective variable } \\
& \mathrm{Y}_{13}=\text { conative variable } \\
& \mathrm{Y}_{14}=\text { action variable }
\end{aligned}
$$

$\delta$ (Delta) $=$ error for exogenous variable

$\varepsilon($ Epsilon $)=$ error for endogenous variable

$\gamma($ Gamma $)=$ coefficient between endogen and exogen variables

$\lambda($ Lambda $)=$ coefficient between latent variables and indicators 
$\beta$ (Betta) $=$ coefficient between endogenous variables

$\zeta$ (Zeta) $\quad=$ error of endogenous latent variable

Based on the complete model of this study, the following can be determined by structural models (structural models) and measurement models (measurement models). A structural equation is an equation that states the relationship between latent variables, and measurement equation is an equation that states the relationship between indicator variables with their latent variables. Measurement Model (Measurement Model) and Structural Model. According to Hair et al. (2010), and Cooper and Schindler (2006).

\section{Result}

The number of respondents is 200 for 4 hotels studied, 50 respondents each. Most male gender is $80 \%$. The reason for staying at the biggest hotel office assignment is $60 \%$ following a business of around $25 \%$, vacation reasons are only $2 \%$. From the summary questionnaire data from the CEM variable assessment, from 19 questions the results above $66.5 \%$ around 14 gave a satisfied and very satisfying assessment. Assessment below $66.5 \%$ and needs to be followed up, among others, related to the hotel atmosphere, sure there is a surprise, good relations with guests and hotels are chosen for future.

Assessment results through questionnaires for variable consumer satisfaction of the 18 questions that gave a satisfied and very satisfied rating above $70 \%$. The results are less satisfied regarding the parking area that is less extensive, as well as for hotels free from drugs. Summary of assessment results from questions through a questionnaire for variables of consumer confidence. Overall guests believe that the hotel performance except for honesty in cleaning the hotel there are still 1.5\% who rate less. Management needs to follow up either by phone or direct visit.

Summary of assessment results from questions through questionnaires for variable Customer loyalty results are some problems for loyalty related to prices. Still not the first choice, about $44 \%$. Some still need information before choosing a hotel and some are still not in line with expectations. Today there are many choices of star hotels that can be easily seen both through the internet, print media, social media. Websites and social media are important to be managed properly.

The influence of CEM on Customer Satisfaction is 0.70. The value of the distribution t count = 4.55 above the $t$ table value $(\alpha \%, 2$-way test $)=1.96$. By because the value of $t$ counts $>t$ table then the null hypothesis is rejected, so concluded that CEM affects customer satisfaction. Thus, the results of the study are in accordance with the theory and support several previous studies such as research by Saleem and Raja (2014), Pozza (2014), and Smith (2008).

The influence of Customer Satisfaction on Trust is 0.55 . The value of the distribution $t$ count $=$ 2.36 above the value of $t$ table $(\alpha=5 \%, 2$-way test $)=1.96$. Because the value of $t$ counts $>t$ table then the null hypothesis is rejected, so that concluded Customer Satisfaction has an effect on Trust. Thus the results research fits theory and supports several studies formerly like Rahardja 
and Dudi (2010), Temkin (2010), and Donelly (2009).

The large influence of Customer Trust on Loyalty is 0.16 . The distribution value t count $=0.21$ below the value of $\mathrm{t}$ table $(\alpha 5 \%, 2$-way test $)=1.96$. Because of the value of $\mathrm{t}$ arithmetic $<\mathrm{t}$ table then the null hypothesis is not rejected, so it is concluded that although Customer Trust has an effect on Customer Loyalty, the effect is small so that it is considered insignificant. Thus, the results of the study do not match the theory and also some previous studies such as Nguyen et al. (2013) and Walter, Mueller dan Helfert (2014). Thus, the results of this study will be discussed further.

The influence of CEM on Customer Loyalty is 0.56 . The distribution value of $\mathrm{t}$ count $=2.00$ above the value of t table $(\alpha 5 \%$, test 2 directions $)=1.96$. Because the value of $\mathrm{t}$ counts $>\mathrm{t}$ table then the null hypothesis is rejected, so it is concluded that CEM has an effect on Customer Loyalty. With

Thus, the results of the study are in accordance with the theory and support several previous studies such as Temkin (2010) and Donelly (2009).

The large influence of Customer Satisfaction on Customer Loyalty amounting to 0.11. The distribution value $t$ count $=0.12$ below the $t$ table value $(\alpha 5 \%$, test 2 direction $)=1.96$. Because the value of $t$ count $<t$ table then the null hypothesis is not rejected, so even though Customer Satisfaction affects Customer Loyalty is considered insignificant. Thus, results research does not fit the theory and also some previous research like Holjevac et al. (2012) and Barsky and Nash (2003). Results this research will be discussed further.

The direct effect of CEM on Loyalty is 0.56 whereas if through the Satisfaction variable as an intervening variable the amount of influence does not exist because satisfaction does not have a significant effect on loyalty. That is, the value of customer loyalty is more caused by CEM marketing compared to caused by customer satisfaction. The direct effect of Satisfaction on Loyalty is 0.11 and not significant, whereas if through the Trust variable as an intervening variable is also insignificant. That is, the value of customer loyalty is only caused by CEM.

Based on the descriptive analysis and causality analysis (the influence between variables), the findings of this study are known, namely (1) As many as 41.5\% of customers who stay in hotels do not feel pleasant memories of staying at a hotel, but rather ordinary memories. To create an experience that will always be remembered by guests, need to innovate services that are different from other hotels with a personal touch that makes them happy and surprise, (2) As many as $47.5 \%$ of customers who stay do not plan to stay again for the future because there are many other hotels in the same area. Need to evaluate the reasons for not planning to stay again, (3) As many as $56.5 \%$ of customers ignored the promotions made by hotel management, (4) As many as $59.0 \%$ of customers are not sure there is a continuous and routine promotion surprise, (5) As many as $48.0 \%$ of customers are disappointed with parking facilities, (6) As many as $61.5 \%$ of customers think that the costs incurred are not in accordance with the benefits or results received, (7) As many as 57.5\% of customers who stay do not state that star hotels are most suitable when compared to other types of hotels between fees and benefits obtained, (8) 


\section{Macrothink}

Business Management and Strategy

ISSN 2157-6068

2018, Vol. 9, No. 2

As many as $81.0 \%$ of customers will question if there is a significant increase in hotel room prices and will try to find another hotel, (9) Based on the theory and results of previous research that Customer Trust has a significant effect on Customer Loyalty. The results of this study state that the influence is weak and can be declared insignificant, (10) Based on the theory and the results of previous research that Customer Satisfaction has a significant effect on Customer Loyalty. The results of this study state that the influence is weak and can be observed.

Structural Equation Result

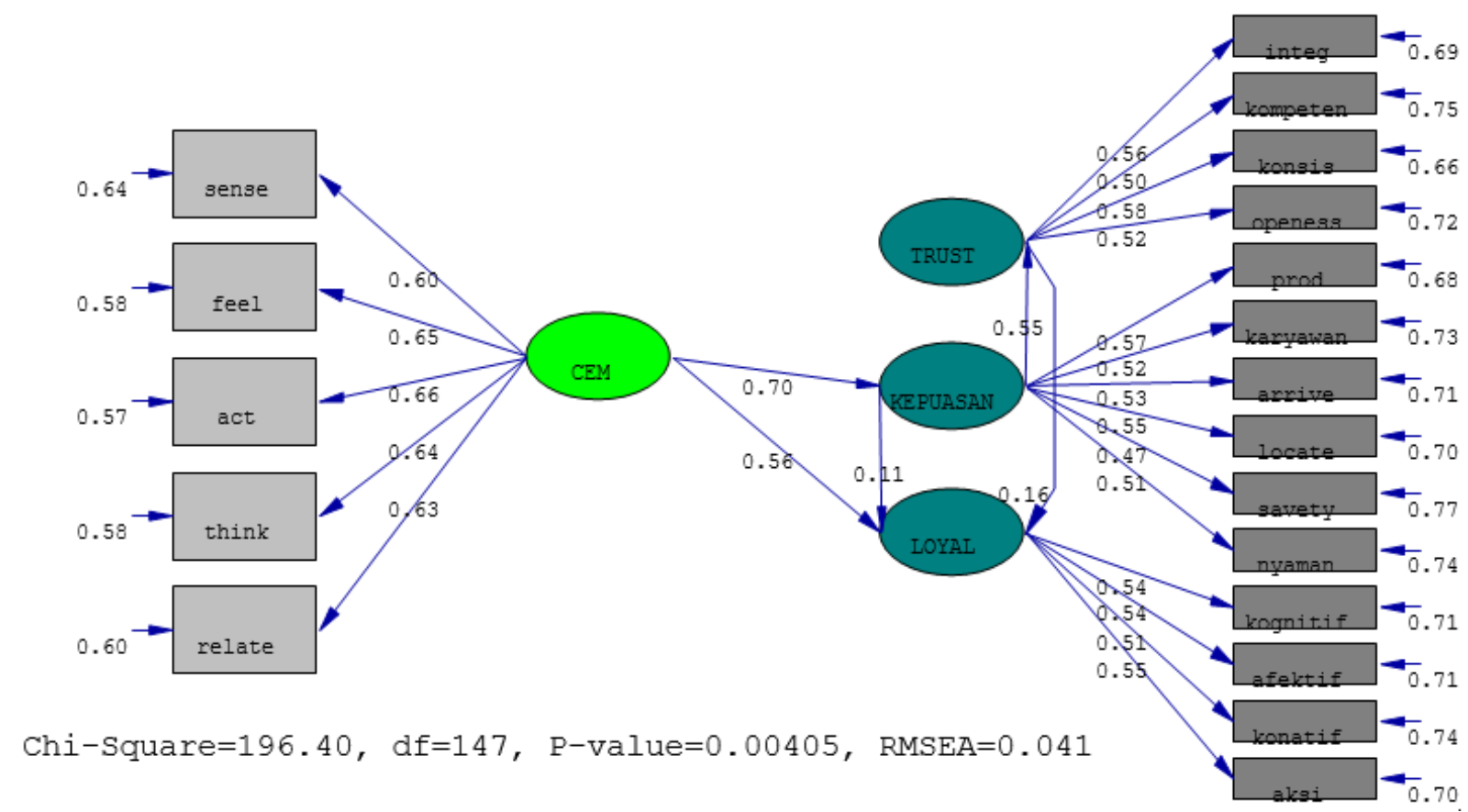

t-statistics result

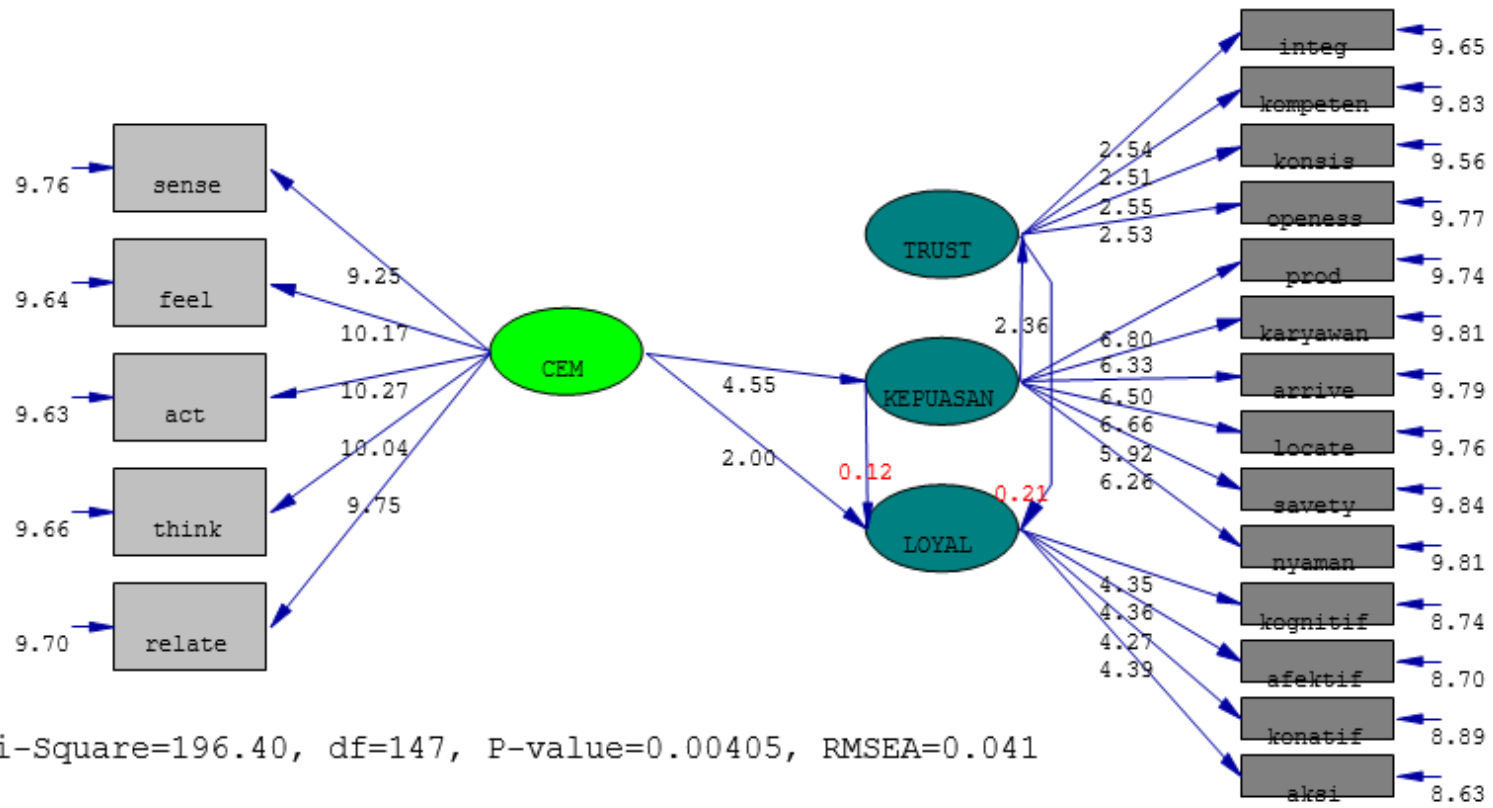




\section{Discussion}

Based on these findings, the findings will be grouped so as to facilitate the discussion, to be:

a. Customers don't get pleasant memories during their stay.

The maximum hotel management efforts in serving hotel guests should always be consistently pursued so that hotel guests can feel high satisfaction to achieve a high level of loyalty. All efforts will eventually return to the attitudes and behavior of customers themselves, depending on the customer's background. Based on respondents' data, it is known that the majority of customers are men who stay for business reasons and office duties. This also means that the focus of customers is not on relaxing but in order to complete work that requires seriousness. The work is done not in the hotel but in the office. Therefore, hotel management must be keen to see its customers so that services can arrive with a sense of pleasure for customers.

b. Customers do not plan to stay again in the future.

Customers do not plan to come back to the hotel for the future due to their attendance on the basis of office or business assignments whose return depends largely on the needs of the task. If there are no similar tasks, other times and the same location, the respondent is certainly not sure that he will come back. Therefore, management needs to have a customer database for adequate promotions. Promotions can be used to attract visitors in the future.

c. Promotional activities carried out by the hotel were not ignored by customers who stayed.

Promotional activities are useful for introducing products, attracting potential customers to transact products sold. Therefore, management should be able to study the market and the forms of promotion that are appropriate for customers. Because customers are dominated by business affairs and office tasks, the appropriate promotion should be carried out. Promotional mix generally consists of advertising, personal selling, sales promotion, publicity, and direct selling.

d. Parking facilities are not managed properly.

Parking facilities for a hotel are needed by visitors. If the number of cars coming can still be accommodated freely it will be different if the parking space is crowded. Guest disappointment will increase if there is more valet parking as a strategy for the hotel to increase revenue from parking. Likewise, if a parking space is placed on a parking ban, the reason is that the place has been ordered by someone.

e. Costs incurred by customers who stay overnight do not match the benefits received.

Although most of the visitors are employees assigned to their offices so that the entire cost of the hotel is borne, they still assume the room price is too expensive. Business people who pay for their own room prices, also assume that the room price is too expensive. Therefore, the hotel needs to reduce the gap between costs and benefits through more services. 
f. The increase in hotel prices will have an impact on moving to another hotel.

Entrepreneurs who spend their own costs during their stay will think again to stay at this hotel if one day they will return. They will easily find replacement hotels. Therefore, the hotel needs to communicate well with hotel guests to make a good impression. Also, the hotel needs to have a business to business relationship with the company that assigns employees to stay at their hotel.

g. Based on the theory and the results of previous research that Customer Satisfaction has a significant effect on Customer Loyalty. The results of this study state that the influence is weak and can be declared insignificant.

The theory states that satisfied customers will have an impact on customer loyalty. Customer satisfaction will move from feeling unsatisfied towards being satisfied and continuing to be very satisfied. The impact on loyalty will begin with a sense of satisfaction that will have little impact on loyalty growth. The higher level of satisfaction will have a more significant impact on loyalists. Therefore, the results of this study where the effect of satisfaction is only weak on loyalty are just natural because the level of satisfaction is still at a stage not very satisfied.

h. Based on the theory and results of previous research that Customer Trust has a significant effect on Customer Loyalty. The results of this study state that the influence is weak and can be declared insignificant.

The theory states that customers who believe in the services provided in accordance with hotel promises will have an impact on customer loyalty. Customer confidence will move from a feeling of unbelief to trust and continue to trust. If customers believe in the consistency of the quality of hotel services, then, in the end, loyalty will be obtained. Even so, trust is not a major factor in customer loyalty, so that a high level of trust has an impact on loyalty. The level of trust that is not yet high only has little impact on loyalty.

\section{Conclusion}

According to the result, it can be concluded that (1) CEM has a positive and significant effect on Loyalty, (2) CEM has a positive effect on customer satisfaction, (3) Customer satisfaction has a positive effect on Customer Trust, (4) The results of this study prove that Customer Satisfaction has a weak or insignificant effect on Customer Loyalty so that it can be stated as having no effect, (5) The results of this study also prove that the influence of customer trust on customer loyalty turns out to have weak influence so that it is declared insignificant.

For hotels that are studied in particular and star hotels in general, it is recommended that services for hotel guests staying overnight do not need to be excessive because most of them are business people and employees assigned to the office. For them, communication facilities and spaces to complete work are more important. Parking facilities are also important, but the excessive valet presence and parking restrictions in certain places are very disappointing. The room price offered by the hotel compared to the benefits received is still considered too 
expensive especially for those who have to pay for themselves. Furthermore, the results of research that Satisfaction has little effect on Loyalty is a finding to be followed up because in theory in certain conditions customer satisfaction has an impact on loyalty. Likewise, customer trust does not have a significant or little effect on loyalty, even though loyalty occurs when customers believe.

Another research suggested is research on the atmosphere of the hotel. The results of the study stating that the atmosphere of the hotel has been underestimated by customers need to be examined to find out the problems to be overcome. Other research is about the lack of sweet memories of guests, lack of desire to stay back, and less attractive hotel promotions. To improve competitiveness it is advisable to innovate and optimize team performance to be more creative and competitive. In the current era of globalization, the demand for information technology development is getting higher. The latest information needs, the ease of gaining access is needed. Continuous development of IT systems must continue. Benchmarking companies that have implemented the system properly. Tight competition with the MEA (Asean Economic Community) allows one country to sell goods and services easily to other countries throughout Southeast Asia. MEA will open up opportunities for foreign workers to enter Indonesia. Human Resources must be continuously given Excellent service training in order to be able to serve better. Application of Reward and punishment for the achievement of KPI (Key Performance Indicator). Try to manage happy team to improve morale. The involvement of top leaders is to support the team's commitment to making improvements

\section{References}

Aspfors, E. (2010). Customer perception of service, store image and product assortment From an interior store perspective. Retrieved from http://www.theseus.fi/bitstream/handle/10024/16719/Aspfors_Emma.pdf?sequence=1\&isAllo wed=y

Barsky, J., \& Nash, L. (2003). Customer satisfaction: Applying concepts to industry-wide measures. Cornell Hotel and Restaurant Administration Quarterly, 43(1), 39-46.

https://doi.org/10.1177/001088040304400523

Bobalca, C. (2013). Study of customers' loyalty: Dimensions and facets. Management and Marketing, XI(1).

Campos, D. F., \& Marodin, T. G. (2012). Perceptions of quality and expectations of hotel services. Journal of Operations and Supply Chain Management, 5(1), 82-99.

Colquitt, J. A., LePine, J. A., \& Wesson, M. J. (2009). Organizational behavior: Improving performance and commitment in the workplace. New York: McGraw-Hill.

Cooper, D. R., \& Schindler, P. S. (2006). Marketing research. NY: McGraw-Hill.

Crandall, C. S., Eshleman, A., \& O’Brien, A. L. (2002). Social norms and the expression and suppression of prejudice: The struggle for internalization. Journal of Personality and Social 
Psychology, 82, 359-378. https://doi.org/doi.10.1037//0022-3514.82.3.359

Donelly, M. (2009). Building customer loyalty: A customer experience based approach in a tourism context. Published Thesis. Retrieved from http://repository.wit.ie/1396/

Fouladivanda, F., Khanmohammadi, Z., Hooman, A., \& Rajabinasr, A. (2013). The relationship between customer experience and service quality. Interdisciplinary Journal of Contemporary Research in Business, 4(9), pp. 316-330. Retrieved from https://journal-archieves27.webs.com/316-330.pdf

Griffin, J. (2005). Customer Loyalty: Growing and Keeping Customers. NY: John Wiley \& Sons.

Haghshenas, L., Abedi, A., Ghorbani, E., Kamali, A., \& Harooni, M. (2013). Review consumer behavior and factors affecting on purchasing decisions. Singaporean Journal of Business Economics and Management Studies, 1(10), 17-24. Retrieved from https://www.singaporeanjbem.com/pdfs/SG_VOL_1_(10)/4.pdf

Hair, J. F., Jr., Black, W. C., Babin, B. J., \& Anderson, R. E. (2010). Multivariate Data Analysis. $7^{\text {th }}$ Edition. NJ: Prentice Hall.

Halimi, A. B., Chavosh, A., \& Choshali, S. H. (2011). The Influence of Relationship Marketing Tactics on Customer's Loyalty in B2C Relationship-the Role of Communication and Personalization, European Journal of Economics, Finance and Administrative Science, $31,49-56$.

Holjevac, I. A., Markovic, S., \& Raspor, S. (2012). Customer satisfaction measurement in hotel industry: Content analysis study. 4th International Scientific Conference" Planning for the future learning from the past: Contemporary Developments in Tourism, Travel \& Hospitality.

Jhamb, D., \& Kiran, R. (2012). Emerging Trends of Organized Retailing in India: A Shared Vision of Consumers and Retailers Perspective. Middle-East Journal of Scientific Research, 11(4), 481-490.

Kheng, L. L., Mahamad, O., Ramayah, T., \& Mosahab, R. (2010). The impact of service quality on customer loyalty: A study of banks in Penang, Malaysia. International Journal of Marketing Studies, 2(2). https://doi.org/10.5539/ijms.v2n2p57

Kotler, P., \& dan Kevin, L. K. (2012). A Framework for Marketing Management, Fourth Edition, Prentice Hall: Pearson Education, Inc.

Maghnati, F., Ling, K. C., \& Nasermoadeli, A. (2012). Exploring the relationship between experiential marketing and experiential value in the smartphone industry. International Business Research, 5(11), 169-177. https://doi.org/10.5539/ibr.v5n11p169

Makodongan, A. (2010). Analisis penerapan program customer relationship management hubungannya dengan loyalitas pelanggan (Studi kasus di Swiss Belhotel Maleosan Manado). 
Jurnal Inovasi, 7(4). Retrieved from http://ejurnal.ung.ac.id/index.php/JIN/article/view/764

Markovic, S., \& Raspor, S. (2010). Measuring perceived service quality using SERVQUAL: A case study of the Croatian hotel industry. Management, 5(3), pp. 195-209.

Medlin, C. J. (2005). Modeling distributor firm and manufacturer firm working relationships. ANZMAC Journal Conference: Business Interaction, Relationships and Networks.

Merisavo, M. (2008). The interaction beetween digital marketing communication and customer loyalty: An integrative model and research propositions. HSE Working papers, W-452, Helsinki School of Economics.

Meyer, C., \& Schwager, A. (2007). Understanding customer experience. Harvard Business Review, 85, pp. 117-26. https://hbr.org/2007/02/understanding-customer-experience

Meyer, C., \& dan Andre, S. (2007). Understanding Customer Experience, Harvard Business Review, February 117-26.

Moellering, G. (2006). Trust: Reason, routine, reflexivity. Oxford: Elsevier.

Nguyen, N., Leclerc, A., \& LeBlanc, G. (2013). The mediating role of customer trust on customer loyalty. Journal of Service Science and Management, 6(1), 96-109. https://doi.org/10.4236/jssm.2013.61010

Omanukwue, E. (2013). Customer perception of service quality in Boutique Hotel Le Six Paris. Unpublished Paper. Retrieved from https://www.academia.edu/9144583/CUSTOMER_PERCEPTION_OF_SERVICE_QUALIT Y_IN_BOUTIQUE_HOTEL_LE_SIX_PARIS.

Pozza, I. D. (2014). Customer experiences as drivers of customer satisfaction. IPAG Working Paper Business School, 185 Boulevard Saint-German, France.

Rahardja, C., \& Dudi, A. (2010). Experiential marketing, customer satisfaction, behavioral intention: Timezone game center Surabaya. The First International Conference Business and Economics, 4(1), 1-6. Retrieved from: https://mpra.ub.uni-muenchen.de/25638/

Robbins, S. P., \& Judge, T. A. (2007). Organizational behavior. New York: Prentice-Hall Jersey.

Saleem, H., \& Raja, N. S. (2014). The impact of service quality on customer satisfaction customer loyalty and brand image: Evidence from hotel industry of Pakistan. IOSR Journal of Business and Management, 16(1), 117-122. Retrieved from http://iosrjournals.org/iosr-jbm/papers/Vol16-issue1/Version-6/O01616117122.pdf

Salo, J., \& Karjaluoto, H. (2007). A conceptual model of trust in the online environment. Online Information Review, 31(5), 604-621. https://doi.org/10.1108/14684520710832324

Schmitt, N. (2007). The interaction of neuroticism and gender and its impact on self-efficacy 
and performance, Human Performance, 21(1), 49-61. doi.org/10.1080/08959280701522197

Schmitt, N. (2014). Personality and cognitive ability as predictors of effective performance at work. Annual Review of Organizational Psychology and Organizational Behavior, 1, 45-65. https://doi.org/10.1146/annurev-orgpsych-031413-091255

Sekaran, U. (2003). Research methods for business: A skill building approach. $4^{\text {th }}$ Edition. Hoboken, NJ: John Wiley \& Sons.

Sirdeshmukh, D., Singh, J., \& Sabol, B. (2002). Customer trust, value, and loyalty in $\begin{array}{llll}\text { relational exchanges. Journal of } & \text { Marketing, 66(1), }\end{array}$ https://doi.org/10.1509/jmkg.66.1.15.18449

Smilansky, S. (2009). Experiential marketing: A practical guide to interactive brand experiences. London: Kogan Page.

Sorce, P. (2002). Relationship Marketing Strategy. Rochester, New York: Printing Industry Center.

Staphit, E. (2013). Tourists' perception of memorable experiences: Testing the memorable tourism experience scale (mtes) among tourists to Rovaniemi, Lapland. Tourism Research Journal, EMACIM Studies.

Temkin, B. D., Chu, W., \& Catino, S. (2010). The customer experience Index 2010. Forrester Research Journal.

Walter, A., Mueller, T., \& Helfert, G. (2014). The impact of satisfaction, trust, and relationship value on commitment: Theoretical considerations and empirical results. Retrieved from https://www.impgroup.org/uploads/papers/131.pdf

Yang, Z.Y., \& He, L.Y. (2011). Goal, customer experience and purchase intention in a retail context in China: An empirical study. African Journal of Business Management, 5(16), 6738-6746. https://doi.org/10.5897/AJBM10.1287

Yuan, Y. H. E., \& Wu, C. K. (2008). Relationships among experiential marketing, experiential value, and customer satisfaction. Journal of Hospitality \& Tourism Research, 32(3), 387-410. https://doi.org/10.1177/1096348008317392

Zeithaml, V. A., Berry, L. L., \& Parasuraman, A. (1988). Communication and control processes in the delivery of service quality. Journal of Marketing, 52, 35-38.

\section{Copyright}

Copyright for this article is retained by the author(s), with first publication rights granted to the journal.

This is an open-access article distributed under the terms and conditions of the Creative Commons Attribution license (http://creativecommons.org/licenses/by/4.0/). 